\title{
Thermal Degradation Studies of Some Strongly Acidic Cation Exchange Resins
}

\author{
Pravin U. Singare ${ }^{* 1}$, Ram S. Lokhande ${ }^{2}$, Rupa S. Madyal ${ }^{3}$ \\ ${ }^{1}$ Department of Chemistry, Bhavan's College, Andheri, Mumbai, India \\ ${ }^{2}$ Department of Chemistry, University of Mumbai, Vidyanagari, Santacruz, Mumbai, India \\ ${ }^{3}$ Department of Chemistry, South Indians' Welfare Society College, Sion, Mumbai, India \\ E-mail: pravinsingare@vsnl.net \\ Received April 19, 2011; revised June 13, 2011; accepted July 22, 2011
}

\begin{abstract}
The thermal degradation of some sulfonic cationites namely Amberlite IR-120, Indion-223 and Indion-225 was investigated using instrumental techniques like thermal analysis (TG) and Scanning Electron Microscopy (SEM). Fourier Transform Infrared Spectroscopy (FTIR) was used to characterize the resins degradation steps. The sulfonic cationites undergo degradation through dehydration, followed by decomposition of sulfonic acid functional groups liberating $\mathrm{SO}_{2}$. The thermogravimetric analysis of above cationites at higher temperature up to $520^{\circ} \mathrm{C}$, show mass loss of $61.61 \%$ and $25.43 \%$ respectively for Indion-223 and Indion- 225 , while Amberlite IR-120 cationite get burned off completely.
\end{abstract}

Keywords: Sulfonic Cationites, Thermal Degradation, FTIR, SEM, Nuclear Resin, Thermal Analysis

\section{Introduction}

Ion-exchange resins are produced and commercialized in a wide range of formulations with different characteristics, and have now a large practical applicability in various industrial processes, such as chemical, and nuclear industry for treatment of liquid waste [1-16]. For their versatile properties, the cationic resins are used both in the ion exchange area and in the heterogeneous catalysis field [17]. These resins exhibit a high exchange capacity and an excellent osmotic shock resistance. So, the cationic resins, produced with a high degree of purity, became important as catalysts in various food technologies [18] and for purification in heavy-water moderated nuclear reactors in nuclear industries [19-21]. In many cases their use is limited by the relatively low thermal stability [22]. Hence, knowledge of the thermal behavior of cation exchange resins is necessary. Abundant data exist on the thermal degradation of anion exchange resins $[23-25]$ and on carboxylic cationites with low acidity [26-27]; literature seems to offer relatively poor information on polystyrene-divinylbenzene sulfonic cationites [28-33]. Therefore, in the present investigation thermal degradation of strongly acidic sulfonic cationites was performed to understand the degradation steps and to compare the relative thermal stability.

\section{Experimental}

\subsection{Materials}

The following commercial cationites were used:

- Strongly acidic gel-type resin with sulfonic acid functionality based on styrene-divinylbenzene matrix: Amberlite IR-120 (Rohm and Haas Co, USA).

- Nuclear grade strongly acidic gel-type resin with sulfonic acid functionality based on styrene-divinylbenzene matrix: Indion-223 (Ion Exchange India Ltd., Mumbai).

- Strongly acidic gel-type resin with sulfonic acid functionality based on styrene-divinylbenzene matrix: Indion-225 (Ion Exchange India Ltd., Mumbai).

The details regarding the physical properties of cationites used are given in Table 1.

The soluble impurities of the resins were removed by repeated soxhlet extraction using water and occasionally with distilled methanol to remove non polymerized impurities. The resins were then dried over $\mathrm{P}_{2} \mathrm{O}_{5}$ in desiccators at room temperature.

\subsection{Thermal Analysis}

The thermogravimetric experiments were performed on a 
Table 1. The main characteristics of the investigated cationites.

\begin{tabular}{ccccc}
\hline Cationites & $\begin{array}{c}\text { Exchange } \\
\text { Capacity } \\
(\mathrm{mEq} / \mathrm{mL})\end{array}$ & Particle size & $\begin{array}{c}\text { Moisture } \\
\text { Content }(\%)\end{array}$ & $\begin{array}{c}\text { Maximum } \\
\text { Temperature } \\
\text { Stability }{ }^{\circ} \mathrm{C}\end{array}$ \\
\hline Amberlite & 1.9 & $16-50$ mesh & 45 & 121 \\
IR-120 & 1.8 & $0.3-1.2 \mathrm{~mm}$ & 53 & 120 \\
Indion-223 & 2.0 & $0.3-1.2 \mathrm{~mm}$ & 50 & 120 \\
Indion-225 & & & & \\
\hline
\end{tabular}

DTG-60H, (Shimadzu, Japan) thermal analysis system between $30^{\circ} \mathrm{C}-550^{\circ} \mathrm{C}$ using aluminum cell $(6 \mathrm{~mm}$ in diameter and $2.5 \mathrm{~mm}$ in depth). The measurements of resin samples were carried out in nitrogen flow (50 $\left.\mathrm{mL} \cdot \mathrm{min}^{-1}\right)$ at heating rate $\left(\beta=10 \mathrm{~K} \cdot \mathrm{min}^{-1}\right)$. The mass of resin sample used was $\sim 5-20 \mathrm{mg}$. In order to characterize the decomposition steps of the investigated ion-exchange resins, FTIR and Scanning Electron Microscopy (SEM) were used in addition to thermal analysis.

\subsection{FTIR Spectra}

FTIR spectra (in $4000-450 \mathrm{~cm}^{-1}$ range) of thermal decomposed samples, up to the characteristics mass-loss steps temperatures, were recorded in $\mathrm{KBr}$ pellets $(2 \mathrm{mg}$ cationite/200 mg KBr) using a FTIR PerkinElmer 1750 spectrophotometer.

Since in the thermal analysis, the major weight loss was observed between $200^{\circ} \mathrm{C}-400^{\circ} \mathrm{C}$, the resin samples were heated in an oven for $3 \mathrm{~h}$ at $10^{\circ} \mathrm{C}$ higher temperatures above the maximum operating temperature, and also at 200 and $400^{\circ} \mathrm{C}$. The thermal degradation of resin was studied by comparing the spectra of fresh and heated resin samples.

\subsection{Scanning Electron Microscopy (SEM)}

The thermal degradation studies of ion exchange resins was also studied by examining the surface morphology of fresh resin samples and samples heated at $400^{\circ} \mathrm{C}$ using JSM-6380LA Scanning Electron Microscope (Jeol Ltd., Japan).The powders were precisely fixed on an aluminum stub using double-sided graphite tape and then were made electrically conductive by coating in a vaccum with a thin layer of carbon, for 30 seconds and at $30 \mathrm{~W}$. The pictures were taken at an excitation voltage of 10 $15 \mathrm{KV}$ and a magnification of $\times 100$ and $\times 130$.

\section{Results and Discussion}

\subsection{Characterization and Thermal Degradation Study of Amberlite IR-120:}

\subsubsection{TGA Analysis}

Figure 1 represents a dynamic weight loss profile of
Amberlite IR-120 from room temperature to $550^{\circ} \mathrm{C}$. Thermogravimetric curve of Amberlite IR 120 shows $22 \%$ weight loss up to $200^{\circ} \mathrm{C}$ due to moisture content and the weight decreased gradually till $400^{\circ} \mathrm{C}$. Above $400^{\circ} \mathrm{C}$ whole compound burned off completely and weight loss measurement was not possible.

\subsubsection{FTIR Analysis}

Figure 2 shows the IR spectrum of the fresh resin sample Amberlite IR-120. The bands at 2923 and $2876 \mathrm{~cm}^{-1}$ are due to the aliphatic $\mathrm{C}-\mathrm{H}$ stretching absorbance of methyl group in the main chain and in aromatic rings and of methylene group respectively. $\mathrm{SO}_{2}$ asymmetric stretching at $1382 \mathrm{~cm}^{-1}$. Strong band at $1652 \mathrm{~cm}^{-1}$ indicates aromatic $\mathrm{C}=\mathrm{C}$ bond. The four sharp peaks at $1009 \mathrm{~cm}^{-1}$, $1037 \mathrm{~cm}^{-1}, 1126 \mathrm{~cm}^{-1}, 1186 \mathrm{~cm}^{-1}$ are due to $\mathrm{SO}_{3} \mathrm{sym}-$ metric stretching. The peaks at $1500-1600 \mathrm{~cm}^{-1}$ are due to deformation and skeletal vibrations of C-H in DVB. Bands appear at $2366 \mathrm{~cm}^{-1}$ which may be assigned to $\mathrm{O}-\mathrm{H}$ stretching vibration originating from the polymer.

At $200^{\circ} \mathrm{C}$, the $21 \%$ weight loss was observed without any loss of peak in the IR spectra. At $400^{\circ} \mathrm{C}$ IR investigation indicates that the peaks in the region $1500-1000$ $\mathrm{cm}^{-1}$ either shows a general broadening or no longer exists (Figure 3). Non-existence of the SO unit was confirmed by the absence of the peaks from $1500-1000 \mathrm{~cm}^{-1}$, with decomposition of the functional group i.e. sulfonic portions of the ring. But slight broadening of the band is observed at $1652 \mathrm{~cm}^{-1}$ for aromatic $\mathrm{C}=\mathrm{C}$ bond remained unchanged. This corresponds to the few chain scissions in the DVB matrix.

\subsubsection{SEM Analysis}

Figure 4, shows the surface morphology of Amberlite IR-120 resins at room temperature indicating plane spherical structure. At $400^{\circ} \mathrm{C}$, resin show large cracks and thread like appearance on the surface (Figure 5).

\subsection{Characterization and Thermal Degradation Study of Indion-223:}

\subsubsection{TGA Analysis}

Thermogravimetric curve of Indion $-223 \mathrm{H}^{+}$shown in Figure 6. The $30 \%$ weight loss up to $200^{\circ} \mathrm{C}$ can be attributed to moisture content. The second major weight loss begins at $270^{\circ} \mathrm{C}$ and ends at $400^{\circ} \mathrm{C}$, which might be due to slow degradation of side chain and loss of sulphonic functional group. The mass loss from $400^{\circ} \mathrm{C}$ to $521^{\circ} \mathrm{C}$ was gradual which might be due to degradation of styrene/DVB matrix.

\subsubsection{FTIR Analysis}

The IR spectrum of Indion-223 in the $3700-400 \mathrm{~cm}^{-1}$ 


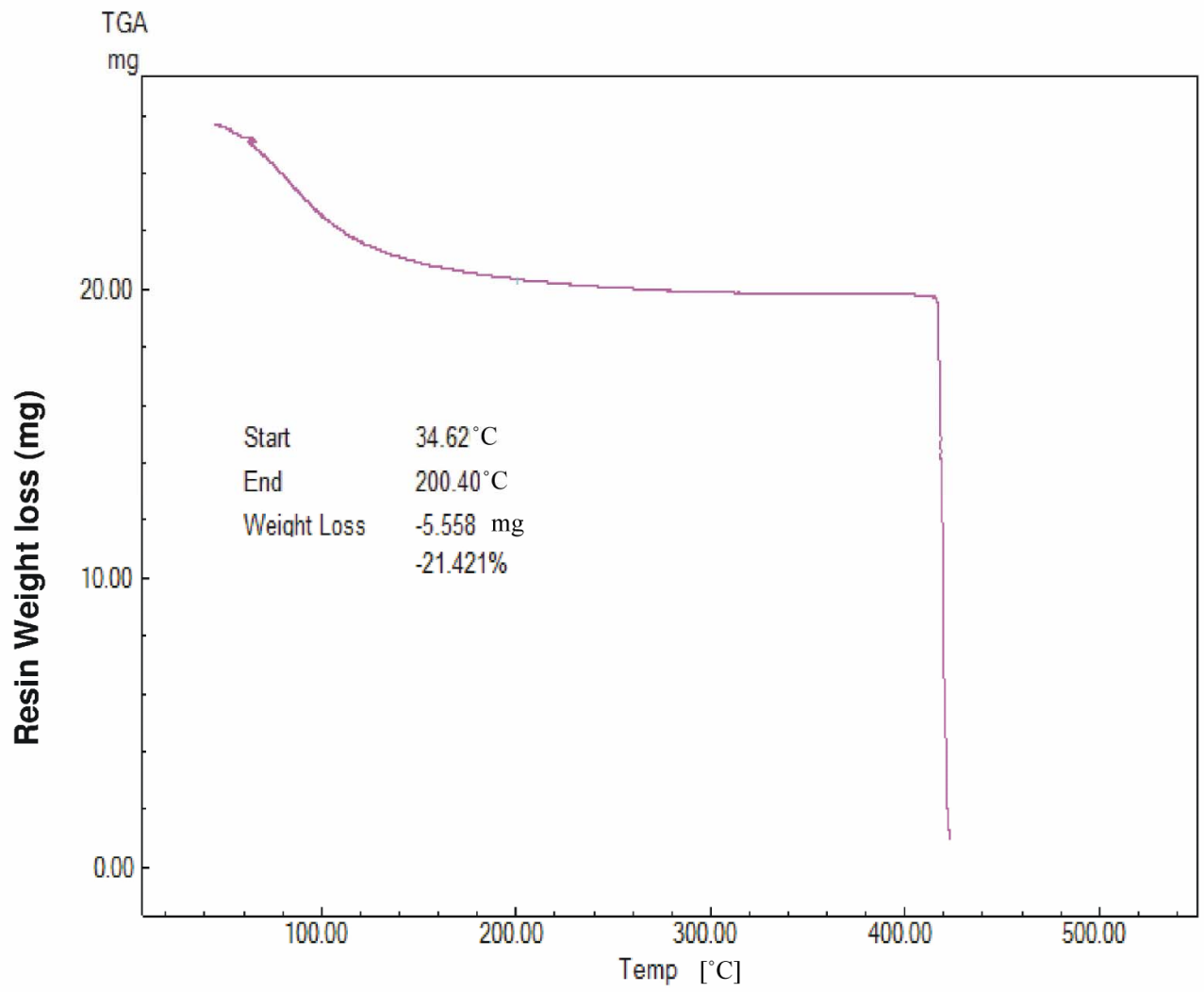

Figure 1. TG curve of Amberlite IR-120.

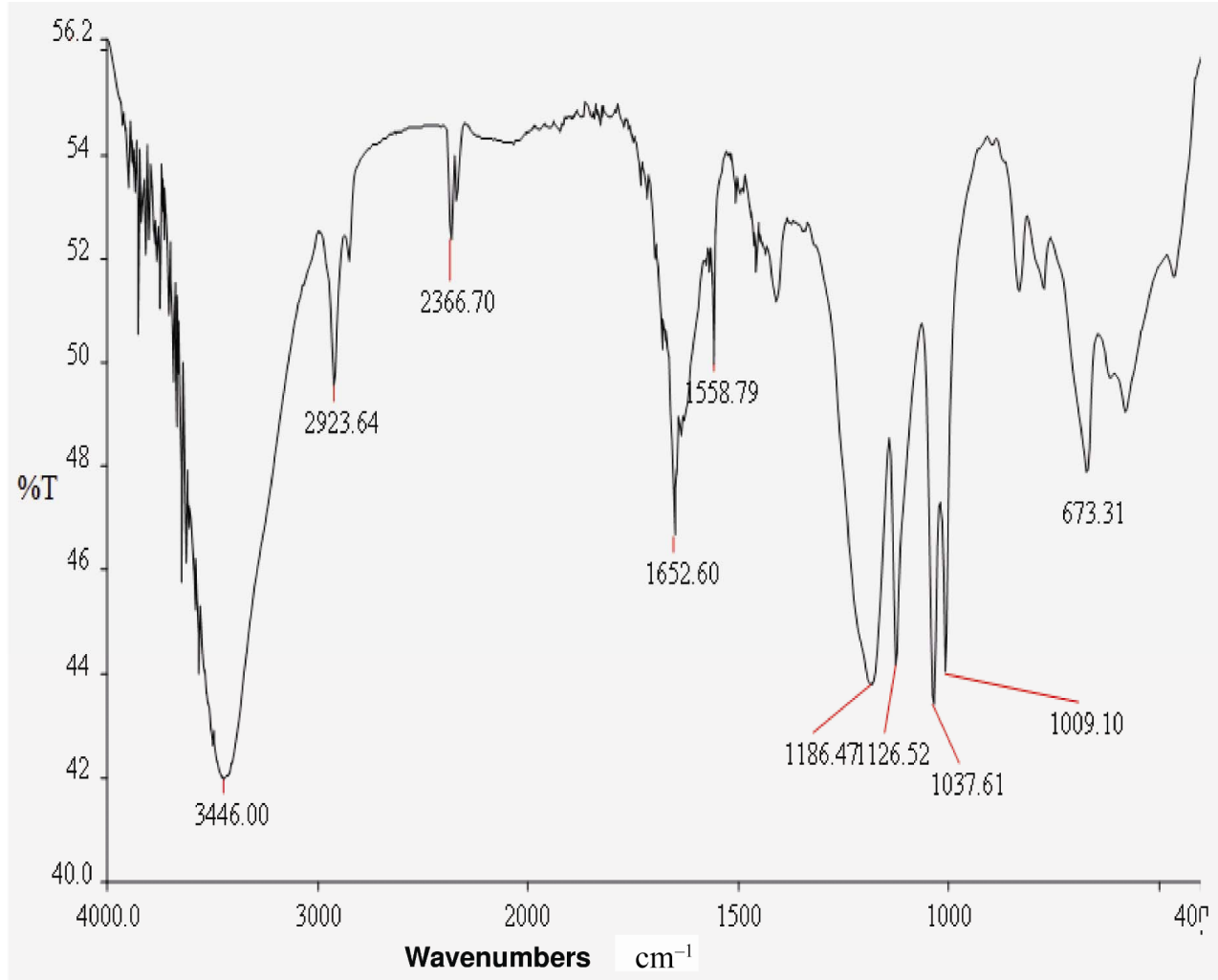

Figure 2. IR spectrum of Amberlite IR-120 at room temperture. 


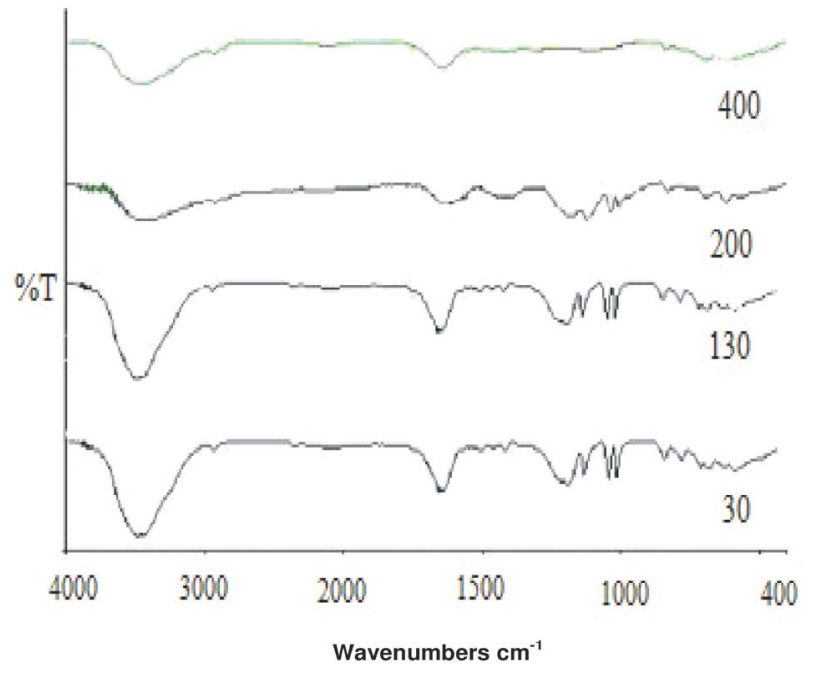

Figure 3. IR spectrum of Amberlite IR-120 at different temperture.

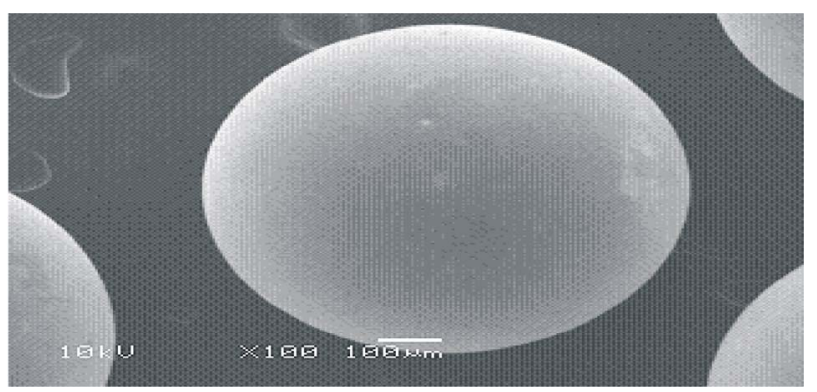

Figure 4. Scanning electron micrograph of the surface of the Amberlite IR-120 at room temperature.

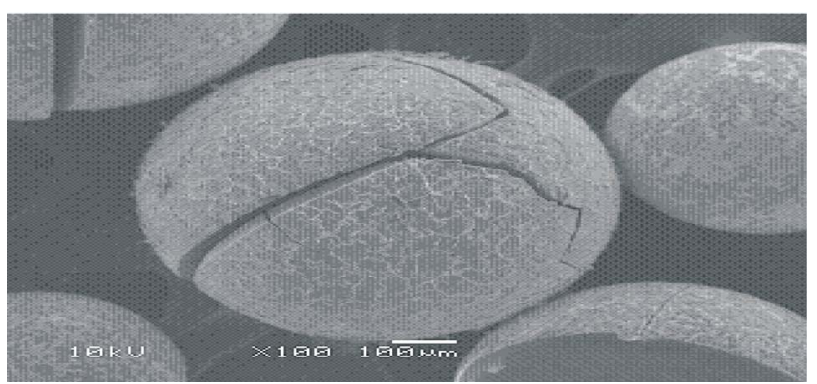

Figure 5. Scanning electron micrograph of the surface of the Amberlite IR-120 at $400^{\circ} \mathrm{C}$.

region is shown in Figure 7. FTIR spectral analysis shows $\mathrm{SO}_{3}$ sharp symmetric stretching band at 1005 $1126 \mathrm{~cm}^{-1}$. O-H stretching at $2364 \mathrm{~cm}^{-1}$. S-O stretching at $668 \mathrm{~cm}^{-1} \cdot \mathrm{SO}_{2}$ asymmetric stretching at $1382 \mathrm{~cm}^{-1}$. $\mathrm{C}=\mathrm{C}$ aromatic nucleus skeletal vibration band at 1500 $1600 \mathrm{~cm}^{-1}$ and $\mathrm{OH}$ hydrogen bonded broad stretching band at $3200-3500 \mathrm{~cm}^{-1}$. The band at $2900 \mathrm{~cm}^{-1}$ attributed to $\mathrm{C}-\mathrm{H}$ stretching vibrations in the main chain and in aromatic rings; the peaks at $1500-1600 \mathrm{~cm}^{-1}$ are due to deformation and skeletal vibrations of $\mathrm{C}-\mathrm{H}$ in Poly-
styrene/DVB.

FTIR investigation shows that that strong bands at 668 $\mathrm{cm}^{-1}, 1019 \mathrm{~cm}^{-1}$ and $1382 \mathrm{~cm}^{-1}$ which are related to SO and $2364 \mathrm{~cm}^{-1}$ stretching frequency of $\mathrm{C}-\mathrm{H}$ units remained upto $200^{\circ} \mathrm{C}$, but at $400^{\circ} \mathrm{C}$ both the groups disappeared (Figure 8). This indicates that at $200^{\circ} \mathrm{C}$ the $29.7 \%$ weight loss is due to moisture, whereas $31.8 \%$ loss is due to the functional group i.e. SO and breaking of $\mathrm{C}-\mathrm{H}$ bond.

\subsubsection{SEM Analysis}

Surfaces of resins at room temperature (Figure 9) and at $400^{\circ} \mathrm{C}$ (Figure 10) were examined by a Jeol JSM6380LA scanning electron microscope. It was found that at $400^{\circ} \mathrm{C}$ resin showed crack in the spherical structure which supports breaking of polymer matrix at that temperature.

\subsection{Characterization and Thermal Degradation Study of Indion-225:}

\subsubsection{TGA Analysis}

Thermogravimetric curve of Indion- $225 \mathrm{H}^{+}$is shown in Figure 11. Thermogravimetric curve shows $\sim 13 \%$ weight loss up to $200^{\circ} \mathrm{C}$, corresponding to the moisture content. Degradation of resin between $270^{\circ} \mathrm{C}-340^{\circ} \mathrm{C}$ takes place sharply and further gradually up to $521^{\circ} \mathrm{C}$ which might be due to decomposition of the sulphonic functional group with rapid evolution of $\mathrm{SO}_{3}$ or $\mathrm{SO}_{2}$ showing mass loss of $\sim 12.5 \%$.

\subsubsection{FTIR Analysis}

The IR spectrum of Indion-225 $\mathrm{H}^{+}$in the $3700-400$ $\mathrm{cm}^{-1}$ region is shown in Figure 12. FTIR spectral analysis shows four sharp peaks at $1009 \mathrm{~cm}^{-1}, 1037 \mathrm{~cm}^{-1}, 1126$ $\mathrm{cm}^{-1}, 1186 \mathrm{~cm}^{-1}$ are due to $\mathrm{SO}_{3}$ symmetric stretching. O$\mathrm{H}$ stretching at $2900-2400 \mathrm{~cm}^{-1}$. S-O stretching at 672 $\mathrm{cm}^{-1} \cdot \mathrm{C}=\mathrm{C}$ aromatic nucleus skeletal vibration band at $1550-1670 \mathrm{~cm}^{-1}$ and $\mathrm{OH}$ hydrogen bonded broad stretching band at $3200-3500 \mathrm{~cm}^{-1}$. The sharp peak at $2900 \mathrm{~cm}^{-1}$ range attributed to $\mathrm{C}-\mathrm{H}$ stretching skeletal vibrations of C-H in Polystyrene/DVB.

The degradation occurs in a single step and mass loss is $25 \%$ up to $521^{\circ} \mathrm{C} . \mathrm{SO}_{2}$ is the dominate product evolved at $190^{\circ} \mathrm{C}$ and $380^{\circ} \mathrm{C}$ while water is also present during the entire degradation pathway but in relatively small amount. Loss of SO unit can also be confirmed by IR investigation. The characteristic band for SO unit at 1009 $\mathrm{cm}^{-1}, 1037 \mathrm{~cm}^{-1}, 1126 \mathrm{~cm}^{-1}, 1186 \mathrm{~cm}^{-1}$ are no longer exist (Figure 13). The evolution of water occurs in the same temperature regime as $\mathrm{SO}_{2}$, between 185 and $400^{\circ} \mathrm{C}$, as spectrum at $200^{\circ} \mathrm{C}$ shows broadened bands indicating slight decrease in SO content. This is likely due to the 


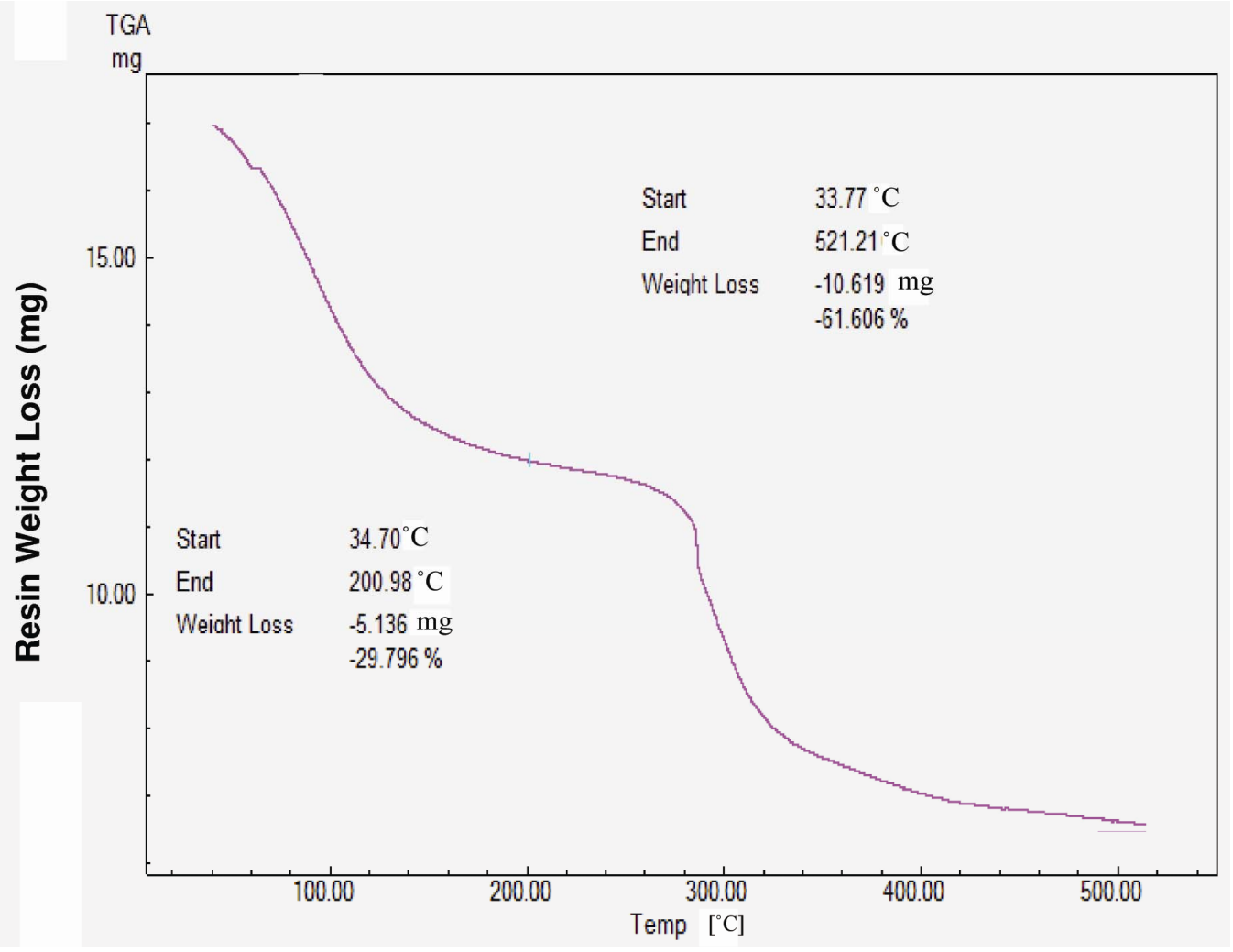

Figure 6. TG curve of Indion-223.

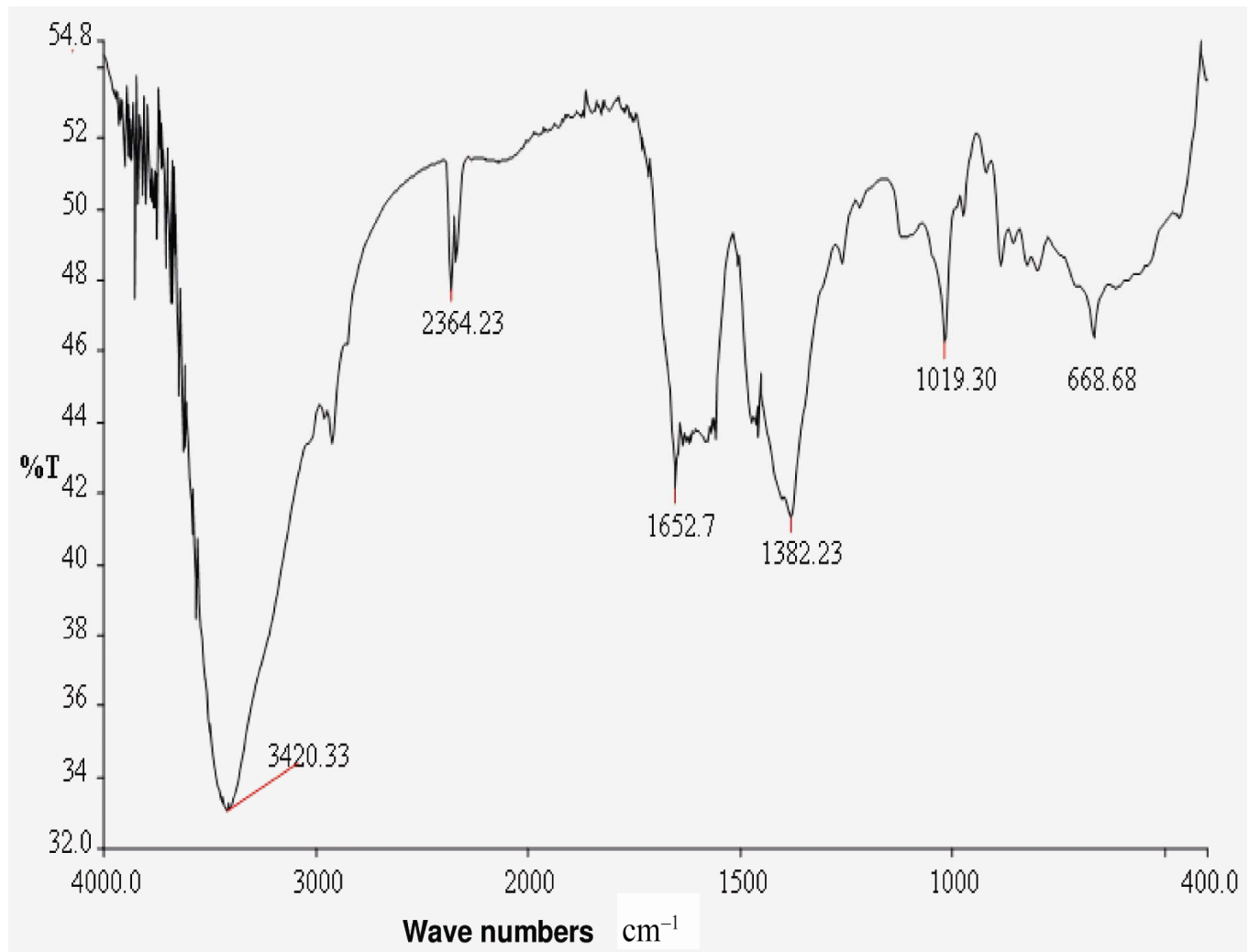

Figure 7. IR spectrum of Indion-2223 at room temperature. 


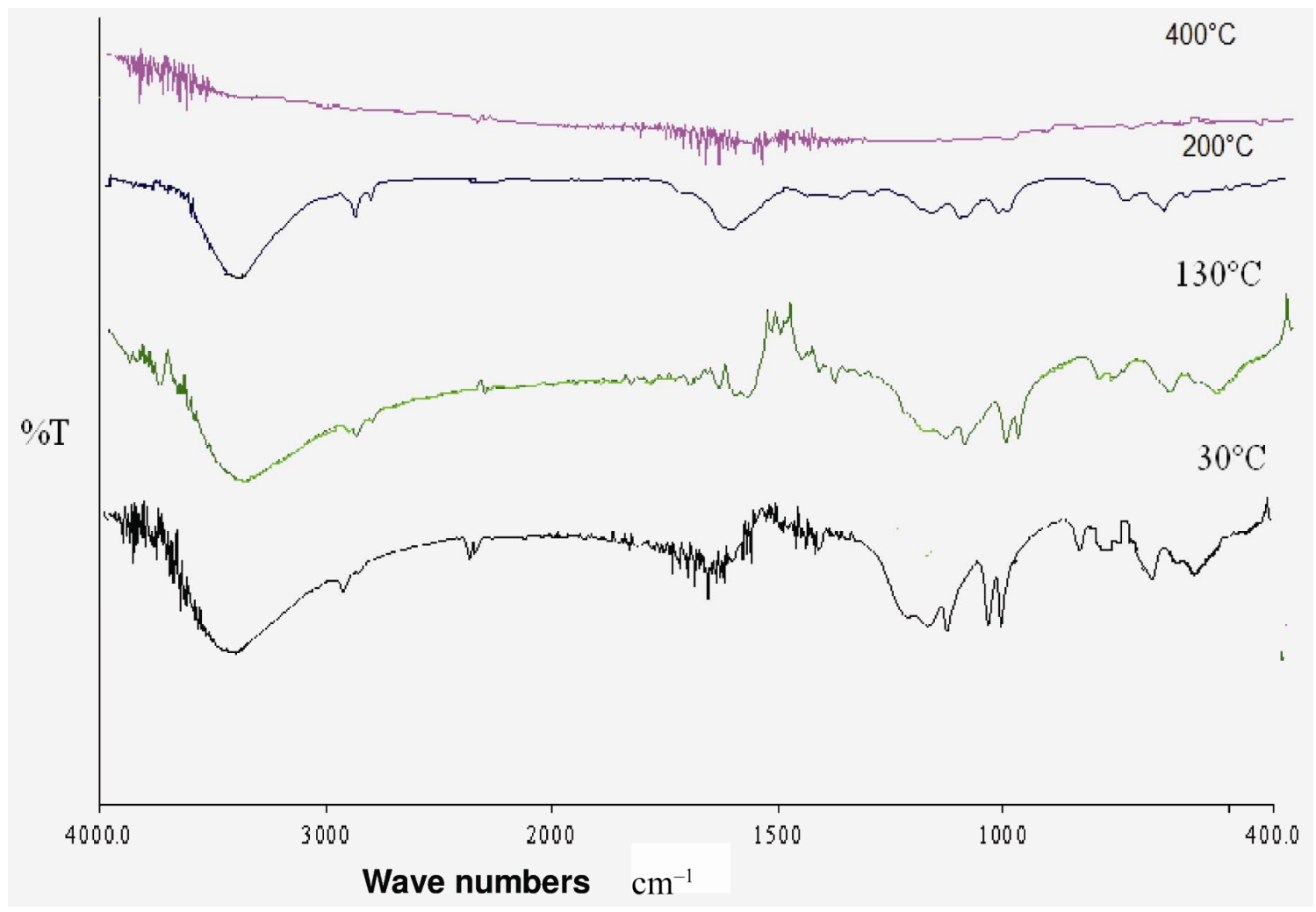

Figure 8. IR spectrum of Indion-2223 at different temperature.

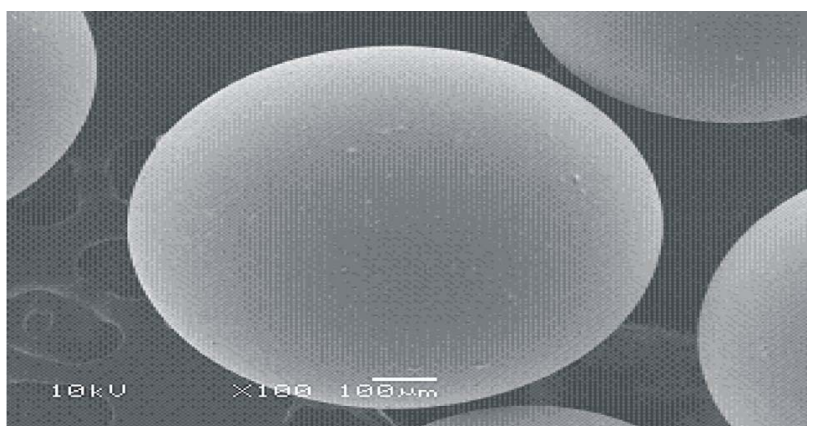

Figure 9. Scanning electron micrograph of the surface of the Indion-223 at room temperature.

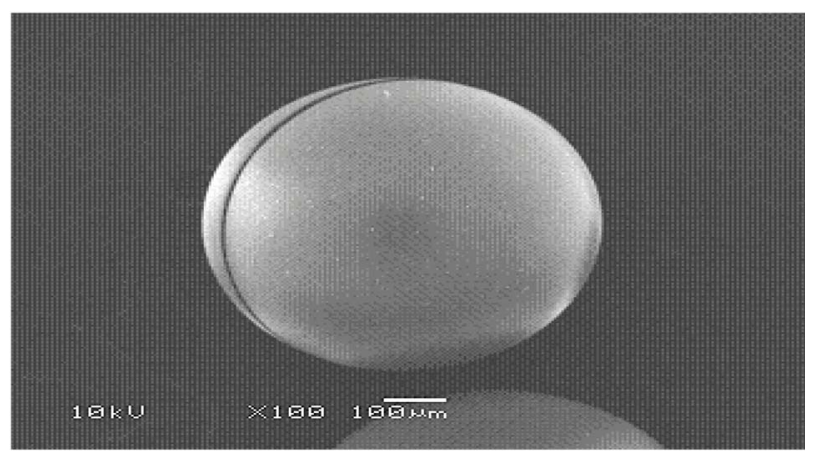

Figure 10. Scanning electron micrograph of the surface of the Indion-223 at $400^{\circ} \mathrm{C}$. formation of sulfurous acid by the process noted above. Water is also evolved early in the degradation and this is likely due to the loss of physically combined water as has been observed for the other compounds [34].

\subsubsection{SEM Analysis}

Figure 14 shows the surface morphology of the Indion- $225 \mathrm{H}^{+}$at room temperature indicating plane spherical structure. Similar to Indion- $223 \mathrm{H}^{+}$; Indion- $225 \mathrm{H}^{+}$ also shows crack on the spherical surface when heated at $400^{\circ} \mathrm{C}$ (Figure 15)

\section{Conclusions}

From the FTIR analysis of three sulfonic acid cationites, it was observed that the degradation takes place through dehydration, followed by decomposition of sulfonic acid functional groups. The thermal analysis shows that up to $200^{\circ} \mathrm{C}$, Indion- 225 cationite shows mass loss of only $13 \%$, as against mass loss of $21 \%$ and $30 \%$ shown by Amberlite IR-120 and Indion-223 respectively. The thermal analysis at a higher temperature up to $520^{\circ} \mathrm{C}$, Amberlite IR-120 cationite gets completely burned, while Indion-225 and Indion-223 shows total mass loss of $25 \%$ and $62 \%$ respectively. Hence the thermal stability of three cationites increases in the order of Amberlite 


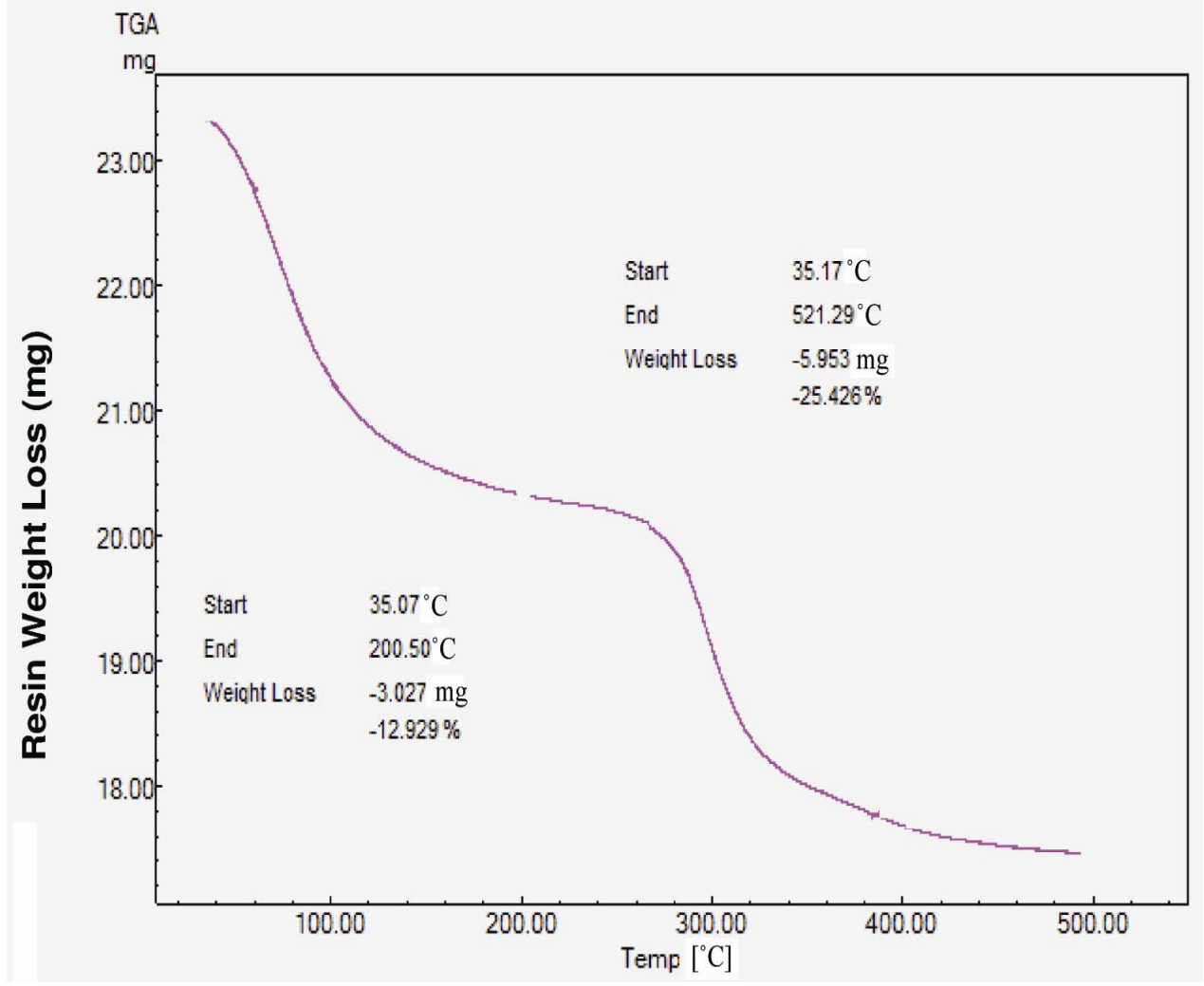

Figure 11. TG curve of Indion-225.

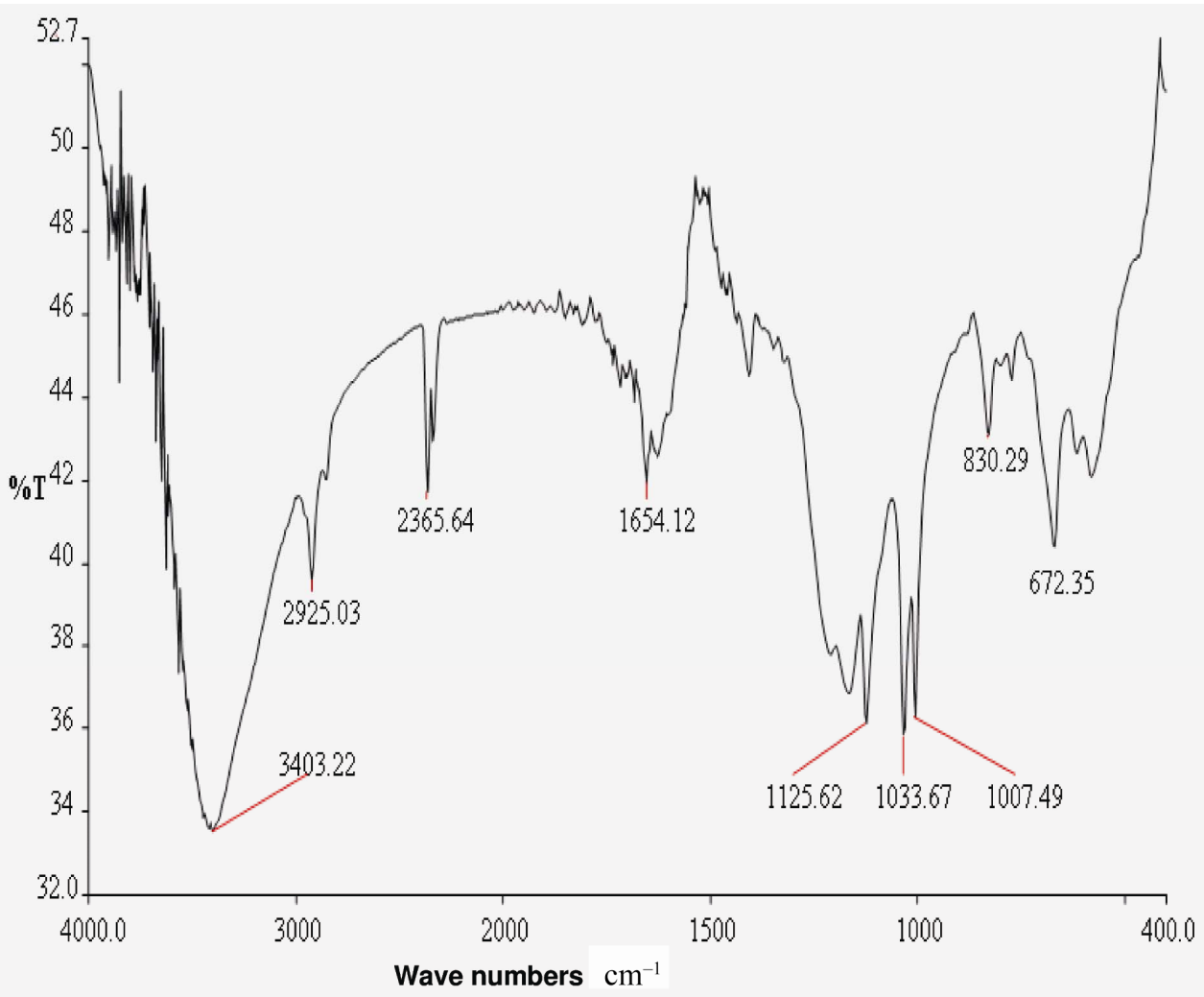

Figure 12. IR spectrum of Indion-2223 at room temperature. 


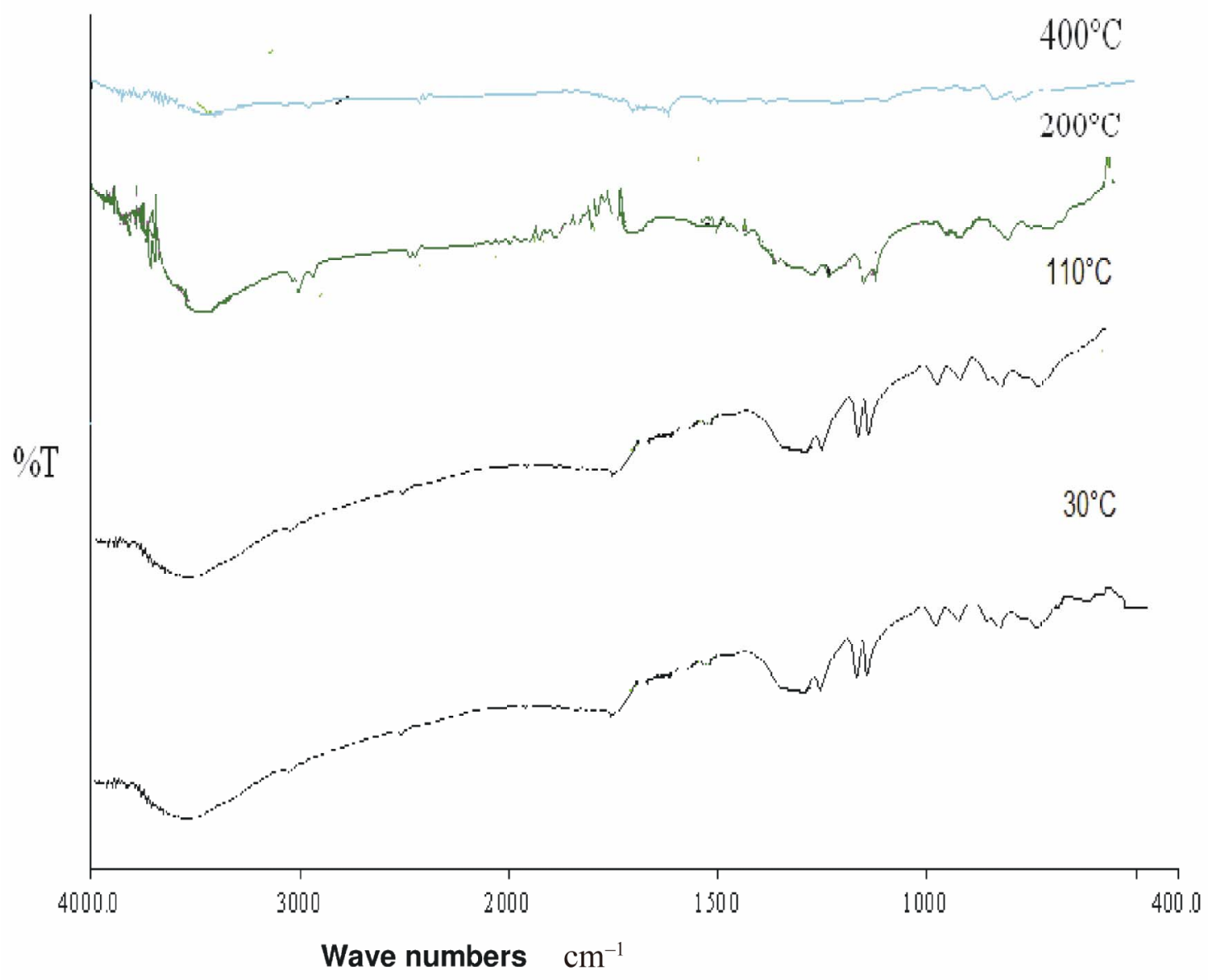

Figure 13. IR spectrum of Indion-2223 at different temperature.

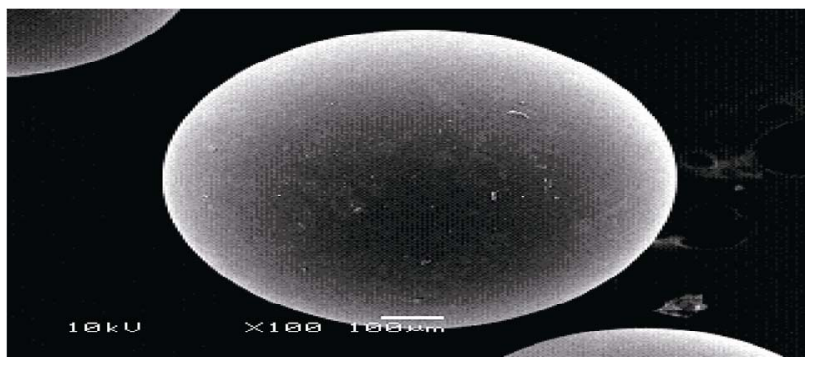

Figure 14. Scanning electron micrograph of the surface of the Indion-225 at room temperature.

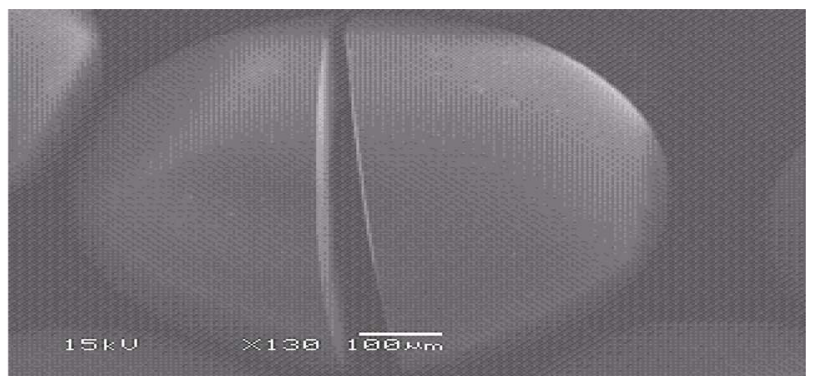

Figure 15. Scanning electron micrograph of the surface of the Indion-225 at $400^{\circ} \mathrm{C}$.
IR-120 $<$ Indion-223 $<$ Indion-225.

\section{References}

[1] R. Lokhande and P. Singare, "Comparative Study on Iodide and Bromide Ion-Isotopic Exchange Reactions by Application of Radioactive Tracer Technique," Journal of Porous Material, Vol.15, No. 3, 2008, pp. 253-258. doi:10.1007/s10934-006-9077-z

[2] R. Lokhande, P. Singare and A. Patil, "Application of Radioactive Tracer Technique on Industrial Grade Ion Exchange Resins Indion-830 (Type-1) and Indion-N-IP (Type-2)," Radiochimica Acta, Vol. 95, No.1, 2007, pp. 111-114. doi:10.1524/ract.2007.95.2.111

[3] R. Lokhande and P. Singare, "Comparative Study on Ion-Isotopic Exchange Reaction Kinetics by Application of Tracer Technique," Radiochimica Acta, Vol. 95, No. 3, 2007, pp. 173-176. doi:10.1524/ract.2007.95.3.173

[4] R. Lokhande, P. Singare and A. Kolte, "Study on Kinetics and Mechanism of Ion-Isotopic Exchange Reaction Using Strongly Basic Anion Exchange Resins DuoliteA101 D and Duolite A-102 D," Radiochimica Acta, Vol. 95, No. 10, 2007, pp. 595-600. doi:10.1524/ract.2007.95.10.595 
[5] R. Lokhande, P. Singare and M. Dole, "Comparative Study on Bromide and Iodide Ion-Isotopic Exchange Reactions Using Strongly Basic Anion Exchange Resin Duolite A-113," Journal of Nuclear and Radiochemical Science, Vol. 7, No. 2, 2006, pp. 29-32.

[6] R. Lokhande, P. Singare and P. Karthikeyan, "The Kinetics and Mechanism of Bromide Ion Isotope Exchange Reaction in Strongly Basic Anion-Exchange Resin Duolite A-162 Determined by the Radioactive Tracer Technique," Russian Journal of Physical Chemistry A, Vol. 81, No. 11, 2007, pp. 1768-1773. doi: $10.1134 / \mathrm{S} 0036024407110088$

[7] R. Lokhande, P. Singare and M. Dole, "Application of Radiotracer Technique to Study the Ion Isotope Exchange Reactions Using a Strongly Basic Anion-Exchange Resin Duolite A-113," Radiochemistry, Vol. 49, No. 5, 2007, pp. 519-522. doi:10.1134/S106636220705013X

[8] R. Lokhande, P. Singare and A. Patil, "Application of Radioactive Tracer Technique for Characterization of some Strongly Basic Anion Exchange Resins," Radiochimica Acta, Vol. 96, No. 2, 2008, pp. 99-104. doi:10.1524/ract.2008.1465

[9] R. Lokhande, P. Singare and S. Tiwari, "Study of Bromide Ion-Isotopic Exchange Reaction Kinetics Using a Weakly Basic Macro Porous Resin Indion-860," Radiochemistry, Vol. 50, No. 6, 2008, pp. 633-637. doi:10.1134/S106636220806009X

[10] R. Lokhande, P. Singare and S. Parab, "Application of Radioactive Tracer Technique to Study the Kinetics of Iodide Ion-Isotopic Exchange Reaction Using StronglyBasic Anion Exchange Resin Duolite A-116," Radiochemistry, Vol. 50, No. 6, 2008, pp. 642-644. doi:10.1134/S1066362208060118

[11] R. Lokhande, P. Singare and V. Patil, "Application of Radioactive Tracer Technique to Study the Kinetics and Mechanism of Reversible Ion-Isotopic Exchange Reactionusing Strongly Basic Anion Exchange Resin Indion -850," Radiochemistry, Vol. 50, No. 6, 2008, pp. 638641. doi:10.1134/S1066362208060106

[12] R. Lokhande, P. Singare and T. Prabhavalkar, "The Application of the Radioactive Tracer Technique to Study the Kinetics of Bromide Isotope Exchange Reaction with the Participation of Strongly Basic Anion Exchange Resin Indion FF-IP," Russian Journal of Physical Chemistry A, Vol. 82, No. 9, 2008, pp. 1589-1595. doi:10.1134/S0036024408090331

[13] R. Lokhande, P. Singare and A. Kolte, "Application of Radioactive Tracer Technique for Characterization of Strongly Basic Anion Exchange Resins Duolite A 101D and Duolite A 102D," Radiochemistry, Vol. 52,No. 1, 2010, pp. 81-86. doi:10.1134/S1066362210010182

[14] R. Lokhande, P. Singare and S. Tiwari, "Application of $82 \mathrm{Br}$ as a Radioactive Tracer Isotope to Study the Bromide Ion-Isotopic Exchange Reaction in Strongly BasicAnion Exchange Resin Duolite-A161," Russian Journal of Physical Chemistry A, Vol. 83, No. 8, 2009, pp. 1389-1394. doi:10.1134/S003602440908024X

[15] S. K. Samanta, T. K. Theyyunni, B. M. MISRA, "Col- umn Behavior of Aresorcinol-Formaldehyde Polycondensate Resin for Radio Cesium Removal Fromsimulated Radwaste Solution," Journal of Nuclear Science and Technology, Vol. 32, No. 4, 1995, pp. 425-429. doi: $10.3327 /$ jnst. 32.425

[16] International Atomic Energy Agency, "Advances in Technologies for the Treatment of Low and Intermediate Level Radioactive Liquid Wastes," Technical Reports Series, No. 370, IAEA, Vienna, 1994.

[17] B. Saha and M. Streat, "Cation Exchange Resin- Catalysed Esterification of Acetic Acid with 2-(1-Cyclohexenyl) Cyclohexanone," Catalysis Letters, Vol. 51, No. 1-2, 1998, pp. 121-127. doi:10.1023/A:1019084901133

[18] E. Dickinson and G. Stanisly, "Colloids and Foods," Applied Science Publisher, London, New York, 1982, p. 220.

[19] International Atomic Energy Agency, "Operation and Control of Ion Exchange Processes for Treatment of Radioactive Wastes," Technical Reports Series, No. 78, IAEA, Vienna, 1967.

[20] International Atomic Energy Agency, "Treatment of Low- and Intermediate-Level Liquid Radioactive Wastes," Technical Reports Series, No. 236, IAEA, Vienna, 1984.

[21] C. Simister, F. Caron and R. Gedye, "Determination of the Thermal Degradation Rate of Polystyrene-Divinyl Benzene Ion Exchange Resins in Ultra-Pure Water at Ambient and Service Temperature," Journal of Radioanalytical and Nuclear Chemistry, Vol. 261, No. 3, 2004, pp. 523-531. doi:10.1023/B:JRNC.0000037092.52163.3d

[22] Yu. Egiazarov, V. Radkevich, L. Kravchuk and A. Ivko, "Thermal Stability and Activity in Hydrogen Oxidation of Palladium Catalysts Supported on Fibrous Sulfonic Cation Exchanger in the Hydrogen and Magnesium Forms," RussianJournal of Applied Chemistry, Vol. 77, No. 9, 2004, pp. 1500-1504. doi:10.1007/s11167-005-0059-8

[23] M. Hyder, S. Bartenev, L. Lazarev, V. Romanovskiy, S. Strelkov, G. Zachinyaev, E. Nazin, A. Aldochin, Y. Glagolenko, A. Maliych and S. Rovniy, "Russian Studies of the Safety of Anion Exchange in Nitric Acid," Separation Science and Technology, Vol. 34, No. 6-7, 1999, pp. 1183-1194. doi:10.1080/01496399908951088

[24] M. Tomoi, K. Yamaguchi, R. Ando, Y. Kantake, Y. Aosaki and H. Kubota, "Synthesis and Thermal Stability of Novel Anion Exchange Resins with Spacerchains," Journal of Applied Polymer Science, Vol. 64, No. 6, 1997, pp. 1161-1167. doi:10.1002/(SICI)1097-4628(19970509)64:6<1161::AI D-APP16>3.0.CO;2-Z

[25] P. Tulupov and N. Polyanskii, "Thermal Stability of Anion-ExchangeResins," Russian Chemical Review, Vol. 42, No. 9, 1973, pp. 754-771. doi:10.1070/RC1973v042n09ABEH002730

[26] A. Chapiro and P. Seidler, "Preparation et Proprietes de Quelques Membranes Semi-permeables Obtenues par Greffage de Films de Polytetrafluoroethylene dans leur Masse," European Polymer Journal, Vol. 1, No. 3, 1965, 
pp. 189-205. doi:10.1016/0014-3057(65)90037-6

[27] D. Chambree, C. Iditoiu, E. Segal and A. Cesaro, "The Study of Non-isothermal Degradation of Acrylic Ion-ExChange Resins," Journal of Thermal Analysis and Calorimetry, Vol. 82, No. 3, 2005, pp. 803-811. doi:10.1007/s10973-005-0967-0

[28] C. Iditoiu, E. Segal and D.Chambree, "Kinetics of Non-isothermal Behaviour of Synthetic Cationites with Low Acidity," Journal of Thermal Analysis and Calorimetry, Vol. 56, No. 1, 1999, pp. 407-417. doi:10.1023/A:1010171222225

[29] C. Iditoiu, C. Popescu and D. Chambre, "Non-isothermal Dehydration Kinetics of Some Cationites," Journal of Thermal Analysis and Calorimetry, Vol. 55, No. 3, 1999, pp. 885-893. doi:10.1023/A:1010142102614

[30] M. Matsuda, K. Funabashi, T. Nishi, H. Yusa and M. Kikuchi, "Decomposition of Ion Exchange Resins by Pyrolysis," Nuclear Technology, Vol. 75, No. 1, 1986, pp. 187-193.
[31] M. Matsuda, K. Funabashi and H. Yusa, "Influence of Functional Sulfonic Acid Group on Pyrolysis Characteristics for Cation Exchange Resin," Journal of Nuclear Science and Technology, Vol. 24, No. 2, 1987, pp. 124128. doi: $10.3327 /$ jnst. 24.124

[32] S. Petterson and G. Kemmler, "Experience of Resin Pyrolysis," Waste Management, Arizona Board of Regents, Vol. 2, 1984, pp. 223-225.

[33] L. Petrus, E. Stamhuis and G. Joosten, "Thermal Deactivation of Strong-Acid Ion-Exchange Resins in Water," Industrial and Engineering Chemistry Product Research and Development, Vol. 20, No. 2, 1981, pp. 366-371. doi: $10.1021 / \mathrm{i} 300002 \mathrm{a} 026$

[34] B. Boinon, D. Ainad-Tabet and J. Montheard, "Thermal Degradation of Poly Ortho Chloro Methyl Styrene and Polymetachloromethylstyrene," Polymer Degradation and Stability, Vol. 28, No. 2, 1990, pp. 197-207. doi:10.1016/0141-3910(90)90006-S 